\title{
Breeding biology of two sympatric coots with contrasting conservation status
}

NICO VARO

Estación Biológica de Doñana, CSIC Sevilla, Spain

Capsule Red-knobbed Coots Fulica cristata and Common Coots Fulica atra have similar breeding biology except in chick survival, which was significantly lower in Red-knobbed Coots.

Aims To provide information on the breeding biology of Red-knobbed Coots in Spain and to compare this with similar data for Common Coots.

Methods During two consecutive breeding seasons, clutch size, egg size, brood size and chick survival of Red-knobbed and Common Coots were studied in nearly all of the lagoons in which Red-knobbed Coots were breeding.

Results Clutch size was similar in the two species. Egg volume varied between years within species. Both species had similar brood sizes but chick survival differed significantly, being lower in Red-knobbed Coots (36\% and 55\% in 2002 and 2003, respectively) than in Common Coots (93\% and 91\% in 2002 and 2003, respectively). The number of fledglings per pair was lower in Red-knobbed Coots (0.9 and 2.1 in 2002 and 2003, respectively) than in Common Coots (2.2 and 3.0 in 2002 and 2003, respectively).

Conclusion The disparity in productivity between Red-knobbed and Common Coots in the lagoons of southern Spain is mainly due to differential chick survival rates. These differences could be the key factor that has led to their currently different conservation status in Spain.

RED-KNOBBED COOTS FULICA IRISTATA AND SYMPATRIC COMMON COOTS FULICA ATRA WERE ABUIDANT AND WIDELY DISTRIBUTED IN SPAIN UNTIL THE BEGINIING OF THE 20TH CENTURY (CRAMP \& SIMMONS 1980, TAYIOR $\&$ VAI PERLO 1998, AMAT \& RAYA 2004), HOWEVER, RED KMOBBED COOTS EXPERIEYCED A DRAMATIC POPU. LATION DECLINE DURING THAT CENTURY, DISAPPEARING FROM THE CENTRAL AND EASTERI REGIONG OF SPAIN (BERNIS 1964, FERRER 1981). (URRENTLY, RED·KNOBBED COOTS HAVE A VERY UNFAVOURABLE CONGERVATIOI STATUS IN THEIR EUROPEAN RANGE (IUCA 1994), BREEDING IN ONLY A FEW LAGOONS IN SPAIN (CRAMP \& SIMMONS 1980, TAYLOR \& VAI PERLO 1998, AMAT $\sigma$ RAYA 2004), ALTHOUGH THEY ARE LOCALLY COMMON TO ABUNDANT IN SUB. SAHARAI AFRICA (WETLANDS INTERMATIONAL 2002). IN CONTRAST, COMMON COOTS HAVE DISPLAYED A VERY DIFFER. ENT POPULATIOI TRAJECTORY II THE PAST CEITURY, AND STILI REMAII WIDESPREAD AND ABUNDANT IN SPAIN (CRAMP $v$ SIMMONS 1980, FERMANDEZPALACIOS \& RAYA 1991, TAYIOR \& VAN PERLO 1998).

THE POPULATION DECLINE OF RED-KNOBBED COOTS HAS

Email: nico@ebd.csic.es
BEEN ATTRIBUTED TO EXCESSIVE HUITING AND EGG COLLECTION (VALVERDE 1960), AND DEGRADATION AND IOSS OF HabITATS (AMAT \& RAYA 2004). HOWEVER, IT If YOT (LEAR WHY THE SAME FACTORS DID IOT SIMULTANEOUSLY AFFECT COMMON COOTS. DISPARITY IN PRODUCTIVITY BETWEEI THE TWO SPECIES COULD BE AI IMPORTANT FACTOR (LACK 1968, ALONSO 1984, NORMENT 1992, SIRIWARDENA IT AL. 1998), AND MORE SPECIFICALLY DIFFERENCES IN THE ABILITY TO ACgUIRE RESOURCES COULD DIFFEREMTIALLY AFFECT BREEDING PERFORMANCE IN THE TWO SPECIES (MARTIY 1987, BRINKHOF G (AVE 1997).

THIS STUDY PROVIDES BASIC INFORMATIOY OY THE BREEDING BIOLOGY OF RED·KMOBBED COOTS IN SPAIN, AND INVESTIGATES WHETHER DIFFEREICES IN PRODUCTIVITY MAY BE CAUSING THE CURREVT DIFFERENT CONGERVATION STATUS OF THE TWO COOT SPECIES IN THIS COUNTRY. FOR THIS PURPOSE, KEY BREED. ING PARAMETERS HAVE BEEN COMPARED, FROM PAIR EOTABLISHMENT TO CHICK SURVIVAL, IN NEARLY ALL LAGOONS IN WHICH RED'KYOBBED COOTS BREED OYMPATRICALLY WITH COMMON COOTS. THE RELATIONSHIP BETWEEI THE MEAN TIME SPENT FORAGING BY ADULTS AND THE MEAN NOMBER OF CHICKS RAISED PER BROOD IN BOTH SPECIES HAS ALSO BEEN ANALYSED, 
METHODS

Study area

BREEDING BIOLOGY WAS STUDIED IN 16 LAGOONS IN ANDALUSIA, IN THE MEDITERRANEAN CLIMATE ZONE REGIOI OF SOUTHERI SPAIN (TABLE 1) (ROMERO ET AL, 1998), THE LAGOONS ARE BRACKISH AND SHALIOW, AND ANNUAL WATER LEVELS DEPEND ON RAINFALL, THUS, LAGOOIS SHOW A MARKED SEASONALITY AS WELL AS STRONG VARIATIONS IN WATER LEVELS BETWEEI IEARS (AMAT 1984). IN 2002 AND 2003, WHEN THIS STUDY WAS CONDUCTED, TOTAL ANTUAL RAINFALL WAS, RESPECTIVELI, 550 MM AND 760 MM. ACCORDINGLY, WATER LEVELS WERE IOWER IN 2002 THAN IN 2003, AND 57\% OF LAGOONS DRIED OUT BY THE END OF AUGUST II 2002, BUT ALL REMAINED WET IN 2003.

NEARLY ALL THE STUDY LAGOONS ARE PROTECTED AREAS SURROUNDED BY CULTIVATED FIELDS. THE MAIN SUBMERGED MACROPHYTES SUITABLE AS FOOD FOR COOTS ARE POTAMOGETON PECTIXATUS, RUPPIA \$PP., CHARA \$PP., ZANNICHELIA OBTUSIFOLIA AND MYRYOPHYLLUM SPP. THE MAIN EMERGENT MACRO. PHYTES IN WHICH COOTS USUALLY BUILD THEIR NESTS ARE PHRAGMITES AUSTRALI, TAMARIX AFRICANA, JUNCUS ACUTU, SCIRPUS MARITIMUS AND TYPHA DOMINGENSIS.

Field methods

EACH LAGOON WAS VISITED TWICE A MONTH DURING THE NON. BREEDING PERIOD, AND AT LEAST ONCE A WEEK DURING THE BREEDING PERIOD. IN THE LAGOONS WHERE BOTH COOT SPECIES WERE BREEDIYG (TABLE I), I SEARCHED FOR COOT IESTS AND EOTIMATED THE EMERGENT VEGETATION HEIGHT AS THE AVERAGE OF THREE MEASUREMENTS MADE AROUND THE MEST ( 50 CM). I ALSO CLASGIFIED THE VBGETATION COVER OF THE IEST INTO THE FOLLOWIYG CATEGORIES; 0 , THE NEST WAS UYCOVERED; 1 , $\mathbf{I}-\mathbf{5 0} \%$ OF THE EXTERMAL DIAMETER OF THE NEST COVERED BY EMERGENT VEGETATION; 2, BETWEEN 51 AND 90\% COVERED; 3, > $90 \%$ COVERED.

I VISITED EACH IEST AT LEAST ONCE DURING THE IYCUBATION PERIOD TO RECORD CLUTCH SIZE AND MEASURE BGG DIMEN. SIOYS (LENGTH AND WIDTH) TO THE VEAREST O.I MM WITH A DIGITAL CALLIPER. I MONITORED THE BROODS AND COUNTED THE IUMBER OF CHICKS PER PAIR FROM HATCHING UNTIL THE CHICKS WERE 60 DAYS OLD. FAMILY GROUPS WERE ALWAYS TOGETHER AND STAYED IN THE SAME LOCATION AT LEAOT UNTIL CHICKS WERE 60 DAYS OLD, WHEN THEY ARE YO LOVGER FED BY PARENTS (HORSFALL 1984A, AMAT 1995). ALTHOUGH DETER' MINING THE EXACT NUMBER OF CHICKS HATCHED IN EVERY IEST WAS IMPRACTICAL, THE WEEKLY MONITORING PROGRAMME RECORDED THE NUMBER OF CHICKS IN THE FEW DAYS POST. HATCHING (LESS THAI SIX DAYS) WHILE THEIR PARENTS WERE FEEDING THEM. THE FOLLWING CATEGORIES OF
Table 1. Number of Red-knobbed Coot individuals observed and number of Red-knobbed Coot pairs breeding in the study lagoons during 2002 and 2003.

\begin{tabular}{|c|c|c|c|c|}
\hline \multirow[b]{2}{*}{ Lagoon } & \multicolumn{2}{|c|}{2002} & \multicolumn{2}{|c|}{2003} \\
\hline & Individuals & $\begin{array}{c}\text { Breeding } \\
\text { pairs }\end{array}$ & Individuals & $\begin{array}{l}\text { Breeding } \\
\text { pairs }\end{array}$ \\
\hline Medina $^{a}$ & 19 & 8 & 33 & 11 \\
\hline Jellib $^{b}$ & 0 & 0 & 4 & 1 \\
\hline Montellano & 0 & 0 & 0 & 0 \\
\hline Comisario & 0 & 0 & 0 & 0 \\
\hline Salada de Zorrilla ${ }^{b}$ & 4 & 0 & 9 & 3 \\
\hline Dulce de Zorrilla & 12 & 4 & 7 & 1 \\
\hline Hondilla $^{a}$ & 10 & 4 & 11 & 5 \\
\hline Galiana $^{b}$ & 0 & 0 & 2 & 1 \\
\hline Pilón & 0 & 0 & 0 & 0 \\
\hline Peña & 0 & 0 & 0 & 0 \\
\hline Taraje & 0 & 0 & 0 & 0 \\
\hline Cigarrera & 0 & 0 & 0 & 0 \\
\hline Dehesa de Abajo & 10 & 5 & 13 & 5 \\
\hline Portil & 2 & 0 & 1 & 0 \\
\hline Primera de Palos & 2 & 0 & 3 & 0 \\
\hline Calatilla & 2 & 1 & 3 & 1 \\
\hline
\end{tabular}

${ }^{a}$ Breeding parameters studied in 2002 and 2003. ${ }^{b}$ Breeding parameters studied only in 2003.

CHICK AGE WERE ESTABLISHED; AGE O, CHICKS LESS THAI SIX DAYS OLD; AGE 15, CHICKS 6-15 DAYS OLD; AGE 30, CHICKS 16-30 DAYS OLD; AGE 45, CHICKS 31-45 DAYS OLD; AGE 60, CHICKS 46-60 DAYS OLD.

FINALLY, IN FIVE LAGOONS I RECORDED THE TIME SPENT FORAGING BI BREEDING ADULTS. FOCAL SAMPLING WAS USED (ALTMANN 1974), IN WHICH THE ACTIVITIES OF THE FOCAL INDIVIDUAL WERE CONTINUOUSLY RECORDED DURING THREE' MINUTE SAMPLING PERIODS. FOCAL INDIVIDUALS OF EACH COOT SPECIES FORAGING IN THE SAME AREA WERE ALTERMATELY RECORDED. THE DURATION OF EACH ACTIVITY WAS MEASURED TO THE NEAREOT O.I SECOND AND I DISTINGUISHED BETWEEN 'FORAGIVG ACTIVITIEY' AND 'OTHER ACTIVITIES' (E.G. LOCO. MOTION, PREENING), SUBSEQUENTLY, I ANALYSED THE RELA' TIONSHIP BETWEE THE MEAI TIME SPENT FORAGIIG BY BREEDING ADULTS IN A LAGOON AND THE MEAN SUMBER OF FLEDGLINGS PER PAIR OBgERVED IN THE SAME LAGOON. OBSERVATIONS WERE MADE EACH DAY IN A DIFEERENT LAGOON BETWEEN 08:00 AND 18:00 HOUR' (GMT+2 HOURS) DURING THE THIRD WEEK OF APRIL. AT MOST, I RECORDED THE SAME BIRD ONCE IN THE MORNING AND ONCE IN THE AFTERNOON. THE TOTAL NUMBER OF FOCAL OBSERVATIOIS CONDUCTED WAS 139 AND 205 FOR RED-KMOBBED AND COMMON COOTS, RESPECTIVELY.

Statistical analysis

ALL SECOND BROODS WERE REMOVED FROM THE ANALYSES. 
THE EOTIMATES OF VEGETATION COVER AT THE NEST WERE ANALYSED BY $X^{2}$ TEST. TWO-WAY ANOVAS WERE USED TO EVAL DATE THE EFECTS OF YEAR, SPECIES AND THEIR INTERACTIOI ON EMERGENT VEGETATION HEIGHT AROUID THE VEST (GQUAREROOT TRANGFORMED), AND CLUTCH AND BROOD SIZE (SQUARE. ROOT TRANSFORMED), THE VOLUME OF THE EGGS WAS EOTIMATED USING THE EQUATION $V=0.51 \times L^{2}$ (HOYT 1979), WHERE $L$ IS THE LENGTH AND $B$ If THE BREADTH (MAX. IMUM DIAMETER), THE VOLUME OF THE EGGS WAS AVERAGED BY NEST AND THE BHECT OF SPECIES, IEAR AND THEIR INTER ACTIOYS ON MEAI EGG VOLUME WAS ANALYSED BY USING TWO WAY ANCOVA INCLUDING CLUTCH SIZE AS A COVARIATE.

I BOTIMATED CHICK SURVIVAL RATE AS THE PROPORTIOI OF CHICKS IN A BROOD THAT SURVIVED TO DAY 60, AND ANALYSED THE INTER'SPECIFIC AND ANIUAL VARIATION ON CHICK SURVIVAL RATE (ARCSINE TRANGFORMED) USING TWO WAY ANOVA. THE SLICE OPTION WAS USED TO STUDY ALL SIGNIFI' CANT SPECIES YEAR INTERACTIONS TO COMPARE THE LEVELS OF ONE FACTOR WHILE HOLDING THE OTHER FACTOR FIXED, FINALLY, I CALCULATED THE MEAI PERCENTAGE OF TIME THAT THE ADULTS SPENT FORAGING RELATIVE TO THE TOTAL TIME OF OBGERVATION IN EACH STUDIED LAGOON, AND ANALYSED ITS RELATIONSHIP WITH THE MEAN IUMBER OF FLEDGLINGS PER PAIR OBSERVED BY USIIG A SPEARMAN CORRELATION. STATISTICA 6.0 (STATSOFT INC., TULSA, OKLAHOMA) WAS USED THROUGHOUT.

\section{RESULTS}

RED-KYOBBED COOTS BRED IN SIX LAGOONS IN 2002 (BREED. ING POPULATION SIZE 22 PAIRg) AND BIGHT LAGOONS IN 2003 (BREEDING POPULATIOI SIZL 28 PAIRS) (TABLE 1). IN CONTRAST, COMMON COOTS BRED IN ALL LAGOONS OF THE STUDY AREA IN BOTH YEARS.

THE EGG -LAYING PERIOD OF BOTH COOT SPECIES WAS LARGELY COIYCIDENT BUT SHORTER IN 2002 THAI IN 2003. IN RED. KNOBBED COOTS IT SPANNED FEBRUARYMAY IN 2002 AND MARCH-AUGUST IN 2003 (IN 2002 THE INTERgUARTILE RAIGE WAS FROM THE SECOND FORTNIGHT OF APRIL TO THE HIRT FORTNIGHT OF MAY; IN 2003 THE INTERgUARTILE RAYGE WAS FROM THE FIRST FORTIIGHT OF MAY TO THE SECOND FORTNIGHT OF JUNE), COMMON COOTS LAID CLUTCHES BETWEEI FEBRDARY AND JUNE IN 2002 AND BETWEEN LATE'JANUARY AND SEPTEMBER IN 2003 (2002, INTERgUARTILL RANGE FROM THE SECOND FORTIIGHT OF APRIL TO THE SECOND FORTIIGHT OF MAY; 2003, INTER,UARTILE RAIGE FROM THE SECOND FORTNIGHT OF MAY TO THE SECOND FORTNIGHT OF JUNE). I DID YOT OBSERVE DOUBLE'BROODING IN RED-KNOBBED COOTS DURING 2002, AND ONLY ONE PAIR RENESTED FOLLOWING IESTLING FAILURE, II 2003, FOUR PAIRS OF RED-KMOBBED COOTS DOUBLE-BROODED, BUILDING ANOTHER NEST FOR THE
SECOND CLUTCH IN THE SAME TERRITORIE, DOUBLE'BROODING WAS OBSERVED IN COMMON COOTS IN BOTH 2002 AND 2003, ALTHOUGH IO RECORD WAS MADE OF THE EXACT NUMBER OF PAIRS IN WHICH THIS OCCURRED.

Nest-site characteristics

DURIYG THE TWO STUDY YEARS, THE OCCUPATION OF THE TERRITORIES STARTED AT THE BEGINIING OF JANOARY IN THE TWO SPECIES, AND BOTH APPAREVTLY PREFERRED TERRITORIES WITH AN AREA OF OPEN WATER ADJACENT TO A PATCH OF ABUN· DANT EMERGENT VEGETATION.

NESTS WERE MORE FREQUENTLY ANCHORED TO ABUNDANT EMERGEIT VEGETATIOI $($ FIG, 1$)$ IN RED-KMOBBED $\left(\mathrm{X}^{2}{ }_{3}=\right.$ 9.4, $P<0.05$ AND $X^{2}{ }_{3}=26.8, P<0.001$ IN 2002 AND 2003, RESPECTIVELY) AND COMMON COOTS $\left(X^{2}{ }_{3}=10.9, P\right.$ $<0.05$ AND $X_{3}{ }_{3}=127.2, P<0.001$ IN 2002 AND 2003, RESPECTIVELY). OVERALL, 66\% OF THE NESTS OF RED. KNOBBED COOTS WERE AYCHORED TO PHRAGMITES AUSTRALIS, 25\% TO JUXCU ACUTUS, AND 9\% TO OTHER PLANT SPECIES (E.G. SCIRPUS MARITIMUS, TAMARIX AFRICANA, TYPHA DOMIN. GEMIO). IN COMMON COOTS, 56\% OF THE IESTS WERE AYCHORED TO PHRAGMITES AUSTRALIS, 24\% TO TAMARIX AFRICANA, I1\% TO JUUCUS ACUTUS, AND 9\% TO OTHER PLANT SPECIES (E.G. SCIRPUS MARITIMUS, TYPHA DOMINGENGIS).

EMERGENT VEGETATION HEIGHT (MEAN \pm SE) AT THE SITES WHERE RED'KNOBBED COOTS ANCHORED THEIR IESTS WAS $207.6 \pm 17.46$ CM AND 222.1 \pm 10.27 CM IN 2002 AND 2003, RESPECTIVELY. IN COMMON COOTS, THE HEIGHT WAS $190.6 \pm 16.74$ CM AND $197.8 \pm 5.35$ CM IN 2002 AND 2003, RESPECTIVELY. DIFFERENCES WERE IOT STATISTICALLY SIGNIFICANT BETWEEN SPECIES OR MEAR $(P>0.09$ IN ALL (ASES).

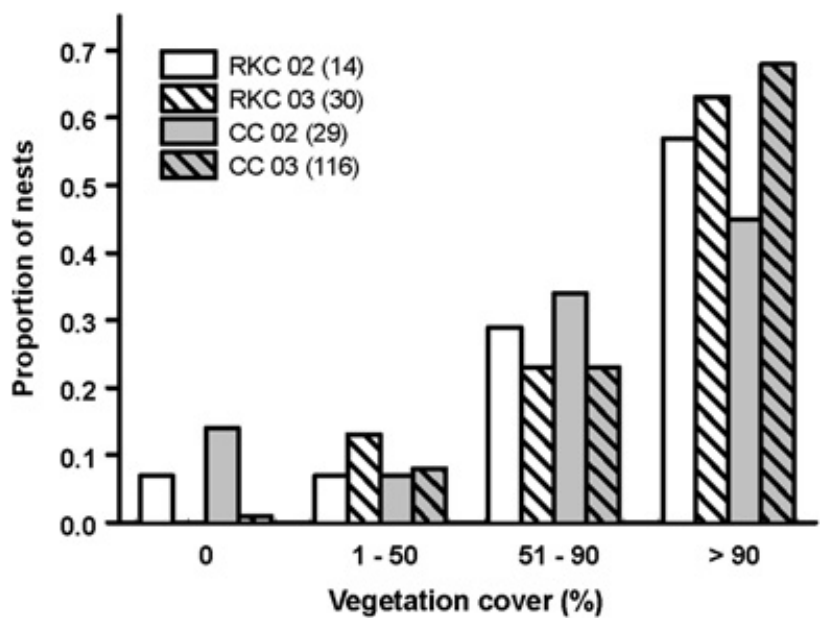

Figure 1. Proportion of nests observed for each vegetation cover class in Red-knobbed (RKC) and Common Coots (CC) in 2002 and 2003. Sample sizes are in parentheses. 
Breeding parameters

AVERAGED BREEDING PARAMETERS BASED ON ABOUT 40 PAIRS OF RED-KNOBBED COOTS AND ABOUT 160 PAIRS OF COMMON COOTS MONITORED DURING 2002 AND 2003 ARE REPORTED IN TABLE 2.

OLUTCH SIZE WAS SIMILAR BETWEEN SPECIES AND IEARS (TABLE 2). EGG VOLUME WAS LARGER IN 2003 THAI IN 2002 IN BOTH RED-KMOBBED AND COMMON COOTS $\left(F_{1,99}=\right.$ 19.7, $P<0.001$, TABLE 2). INITIAL BROOD SIZL WAO SIMILAR BETWEEN SPECIES, AND BOTH SHOWED A LARGER INITIAL BROOD IN 2003 THAN IN $2002\left(F_{1,198}=40.49, \quad P<0.001\right)$. THE SPECIES"YEAR INTERACTION WAS NOT SIGNIFICANT.

THE CHICKS OF EACH SPECIES EXHIBITED A DIFFERENT PATTERT OF SURVIVAL AFTER HATCHING. IN COMMON COOTS IEARLY ALL CHICKS REACHED AGE CLASS 60 (93\% AND 91\% IN 2002 AND 2003, RESPECTIVELY) WHEREAS IN RED-KMOBBED COOTS ONLY 36\% OF THE CHICKS II 2002 AND $55 \%$ OF THE CHICKS IN 2003 SURVIVED TO DAY 60 (FIG. 2). SLICING OF THE SIGNIFICANT SPECIES'YLAR INTERACTIOI $\left(\boldsymbol{F}_{1,184}=\mathbf{5 . 8}, \boldsymbol{P}\right.$ $=0.02$ ) INDICATED THAT DIFFEREYCES IN CHICK SURVIVAL RATE BETWEEN YEARS WERE ONLY SIGNIFICANT IN RED-KNOBBED $\operatorname{coOTS}\left(F_{1,184}=5.8, P=0.02\right)$, WITH \& HIGHER CHICK SURVIVAL RATE IN 2003 THAN IN 2002 (TABLE 2). MOREOVER, DIFFERENCES IN CHICK SURVIVAL RATE BETWEES SPECIES WERE SIGNIFICANT IN THE TWO YEARS $\left(F_{1,184}=71.2, P<0.001\right.$ AND $F_{1,184}=53.9, P<0.001$ IN 2002 AND 2003, RESPECTIVELY), WITH CHICK SURVIVAL IOWER IN RED.KYOBBED THAN IN COMMON COOTS II THE TWO STUDY YEARS (TABLE 2). ALTOGETHER, THE NUMBER OF FLEDGLINGS PER PAIR (TABLE 2) WAS IOWER IN RED'KNOBBED THAN IN COMMON COOTS $\left(F_{1,184}=31.1, P<0.001\right)$, AND IOWER IN 2002 THAI IN 2003 IN THE TWO SPECIES $\left(F_{1.184}=29.9, P<0.001\right)$.

THERE WAS A STATISTICALLY SIGIIFICANT NEGATIVE CORRELA TION IN RED-KYOBBED COOTS BETWEEN MEAN NUMBER OF CHICKS RAISED PER PAIR AND THE MEAI TIME THAT ADULTS

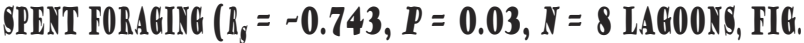
3). HOWEVER, THIS CORRELATION WAS NOT STATISTICALLY
SIGNIFICANT IN COMMON COOTS $\left(\mathbb{f}_{\mathfrak{q}}=-0.521, P=0.18, N\right.$ = 8 LAGOONS, FIG, 3).

\section{DISCUSSION}

II SOUTHERI SPAIN, THE POPULATION OF RED-KMOBBED COOTS IS ENDANGERED AND IT IS ALSO AT THE EDGE OF THE SPECIES DISTRIBUTIOI RANGE (CRAMP \& SIMMONS 1980, TAYIOR \& VAI PERIO 1998, AMAT \& RAYA 2004). THE SPECIES, HOWEVER, DOES NOT FACE COISERVATIOI PROBLEMS IN ITS SUB-SAHARAI RANGE AND POPULATION IS INCREASIIG IN SOME AREAS (E,G. SOUTHERI AFRICA, WETLANDS INTERTATIOYAL 2002). COMMON COOTS ARE A CLOSELI RELATED SPECIES (LIVEZEAY 1998), ABUNDANT IN EUROPE, AND IIVING IN SIMPATRY WITH RED STUDY AREA. THE RESULTS PRESENTED HERE SHOW A DISPARITY IN PRODUCTIVITY BETWEEN THESE TWO SPECIES, MAINLI ATTRIBUTABLE TO DIFFEREVTIAL CHICK SURVIVAL RATES. IT SEEMS PROBabLE THAT THESE ARE RELATED TO A DIFFEREICE IN THE ABILITY OF THESE TWO COOT SPECIES TO ACgUIRE RESOURCES DURING THE BREEDING PERIOD AT THE SAME SITES.

A LARGELY COINCIDENT EGG LAYING PERIOD AND THE ABSEYCE OF DIFFERENCE IN CLUTCH SIZE BETWEES THE TWO STUDY SPECIES DOES YOT APPEAR TO HAVE COITRIBUTED TO THE CONTRAST IN THEIR PRODUCTIVITY IN THE STUDY AREA. THE LAYIYG PERIOD OF COMMON COOTS, SPANNIYG LATE JANUARY TO SEPTEMBER, WAS SIMILAR TO THAT REPORTED II OTHER EUROPEAI REGIOIS (FEBRUARY SEPTEMBER, CRAMP \& SIMMONS 1980, TAYLOR \& VAI PERLO 1998). IN RED. KNOBBED COOTS, HOWEVER, THE LAYING PERIOD OBSERVED STRETCHED FROM FEBRUARY TO AUGUST AND WAS MARKEDLI SHORTER THAI II ITS SUBSAHARAI RAIGE, WHERE BIRDS USUALLY LAI IGGS ALL YEAR ROUND (CRAMP \& SIMMONS 1980, TAYLOR \& VAI PERLO 1998). THESE DATA SUGGLSTED A REDUCED PRODUCTIVITY OF RED KNOBBED COOTS II THE STUDY AREA, WHERE SECOND BROODS WERE IOT FREQUENTLY OBSERVED.

THE CLUTCH SILE OF BOTH SPECIES AVERAGED SIX EGGS AND

Table 2. Reproductive parameters (mean \pm sd) of Red-knobbed and Common Coots in southern Spain during 2002 and 2003.

\begin{tabular}{lrrrrr} 
& \multicolumn{2}{c}{ Red-knobbed Coot } & & \multicolumn{2}{c}{ Common Coot } \\
\cline { 2 - 3 } \cline { 5 - 6 } & \multicolumn{2}{c}{2002} & 2003 & & \multicolumn{2}{c}{2002} & \\
\hline Clutch size & $5.9 \pm 1.28(13)^{a}$ & $5.8 \pm 1.39(27)^{a}$ & & $5.6 \pm 1.50(30)^{a}$ & $6.1 \pm 1.26(129)^{a}$ \\
Egg volume (cm $\left.{ }^{3}\right)$ & $33.52 \pm 3.46(10)^{a}$ & $37.97 \pm 2.88(27)^{b}$ & & $34.11 \pm 3.12(22)^{a}$ & $36.08 \pm 3.08(45)^{b}$ \\
Initial brood size & $2.4 \pm 0.88(15)^{a}$ & $3.7 \pm 1.15(28)^{b}$ & & $2.4 \pm 0.68(46)^{a}$ & $3.4 \pm 1.08(113)^{b}$ \\
Fledglings / pair & $0.9 \pm 1.06(15)^{a}$ & $2.1 \pm 1.62(26)^{b}$ & & $2.2 \pm 0.57(46)^{c}$ & $3.0 \pm 1.10(101)^{d}$ \\
Chick survival* & $0.36 \pm 0.44(15)^{a}$ & $0.55 \pm 0.27(26)^{b}$ & & $0.93 \pm 0.16(46)^{c}$ & $0.91 \pm 0.16(101)^{c}$ \\
\hline
\end{tabular}

Sample sizes (number of pair studied) are in parentheses. Means with the same superscript letter were not significantly different at the $5 \%$ confidence level (two-way ANOVA). *Mean proportion of chicks in a brood that survived to day 60 (see Methods). 


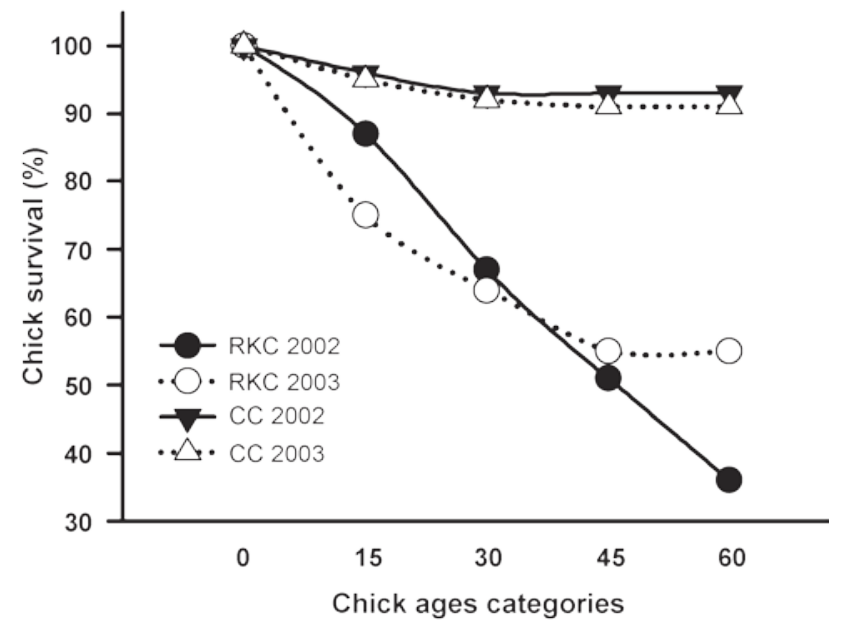

Figure 2. Chick survival patterns from age 0 to age 60 in Redknobbed (RKC) and Common Coots (CC) during 2002 and 2003 in the study lagoons. See Methods for chick age classification.

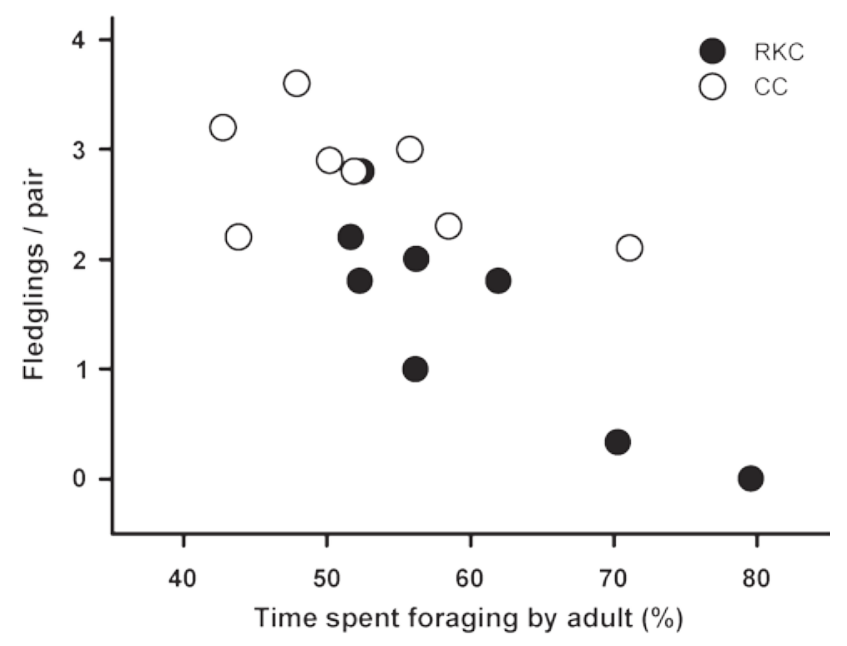

Figure 3. Relationship between the mean number of fledglings per pair and the average time spent foraging by adults in Red-knobbed (RKC) and Common Coots (CC). Each data point denotes a lagoon.

WAS WITHII THE RAYGE OF DATA FOR RED-KMOBBED COOTS IN THEIR SUBSAHARAN RAYGE (FIVE TO SEVEN EGGS, CRAMP \& SIMMONS 1980, TAYLOR \& VAI PERLO 1998), BUT OI THE IOWER SIDE OF DATA REPORTED FOR COMMON COOTS IN EUROPE (SIX TO TEN EGGS, CRAMP \& SIMMONS 1980, TAYLOR \& VAN PERLO 1998).

EGG LAYING PERIOD AND CLUTCH SIZE ARE TWO LIFE-HIOTORI TRAITS THAT DEPEND ON HABITAT CONDITIONG (LACK 1954, PERRINS \& BIRKHEAD 1983, MARTII 1987, DERVIEUX VT AL. 1990, EVANS ET AL. 2005, WEGGLER 2006). THEREFORE, A SHORTER EGG LAYING PERIOD IN RED-KMOBBED COOTS AND A REDUCED CLUTCH SIZE IN COMMON COOTS BOTH INDICATE THAT THE STUDY LAGOONS IN SOUTHERI SPAIN MIGHT YOT BE CURRENTLY OPTIMUM HABITATS FOR COOTS.
BROOD MORTALITY DUE TO STARVATIOI If THE MAIN FACTOR DETERMINING BROOD SIZE IN COOTS (HORSFALL 1984A, AMAT 1995). IN THIS STUDY, BOTH COOT SPECIES SHOWED A SIMILAR BROOD SIZE, ALTHOUGH THEY DIFFERED IY CHICK SURVIVAL, THE CHICK SURVIVAL RATE FOR COMMON COOTS (93\% AND

91\% IN 2002 AND 2003, RESPECTIVELY) WAS SIMILAR TO THAT FOUND IN THE UK (HOROFALL 1984A), AND MOST OF THE CHICKS SURVIVING THE HIRST HEW DAIS AFTER HATCHING ALSO SURVIVED UXTIL FLEDGIYG, HOWEVER, CHICK SURVIVAL WAS MUCH IOWER IN RED KNOBBED COOTS BREEDING SIMUL' TANEOUSLI (36\% AND 55\% IN 2002 AND 2003, RESPECTIVELY), AND IN THE SAME LAGOONS A LARGER PRO. PORTIOI OF CHICKS SURVIVING THE FIRST FEW DAYS AFTER HATCHING DID HINALLY DIE, ABSENCE OF DIFFERENCES IN NESTSITE CHARACTERISTICS BETWEEN THE TWO SPECIES DID NOT SUPPORT A HIGHER PREDATION RISK FOR CHICKS OF RED. KNOBBED COOTS (ALONSO IT AL. 1991, HIPFNER ET AL. 2001, BATARY IT AL. 2004). HOWEVER, THE NEGATIVE RELATIONSHIP BETWEEN THE TIME SPENT FORAGING BY ADULTS AND THE IUMBER OF FLEDGLINGS PER PAIR FOUND ONLY II RED. KYOBBED COOTS SUGGESTED THAT CHICK SURVIVAL OF THIS SPECIES WAS LIMITED BY FOOD AVAILABILITY IN THE STUDY LAGOONS (LACK 1954, MARTIN 1987, BRINKHOF \& CAVÉ 1997, GILL VT AL. 2002).

SOME OF THE BREEDIYG PARAMETERS DID VARY BETWEEN THE TWO STUDY YEARS, WITH CONTRASTING RAINFALL AND WATER LEVELS IN THE LAGOOIG, SUGGESTISG THAT PRODUCTIVITY IN COOTS ALSO DEPENDS ON HABITAT CONDITIONS (BRINKHOF \& CAVE 1997, HALSE \& JaENSCH 1989). IN PARTICULAR, RED-KMOBBED COOTS HAD FEWER BREEDING ATTEMPTS THAI SIMPATRIC COMMON COOTS AND ONLY SOME PAIRS INITIATED SECOND BROODS IN 2003, THE RAINIEST YEAR. EGG VOLUME WAS ALSO HIGHER IN 2003 FOR THE TWO SPECIES, SUGGESTIIG THAT FEMALES FOUND BETTER CONDITIONS II THIS YEAR (HORGFALL 1984B, MARTIN 1987, LU \& ZHENG 2003, JOHYSON IT AL. 2006). THE ABSENCE OF DIFFERENCES IN CLUTCH SIZE BETWEEI YEARS SUGGEOTS THAT BOTH RED. KNOBBED AND COMMON COOTS REDUCED EGG SILE INSTEAD OF OLUTCH SIZE UNDER ADVERSE HABITAT CONDITIONS (JOHYSON ET AL. 2006). II ADDITIOI, INITIAL STARVATION MORTALITY WITHIN BROODS WAS LOWER IN 2003, AND THE TWO COOT SPECIES SHOWED LARGER INITIAL BROOD SIZES IN THIS YEAR. HOWEVER, THE HFFECTS OF YEAR VARIATIOI IN CHICK SURVIVAL RATE WERE ONLY SIGNIFICANT FOR RED-KMOBBED COOTS, RECORDING AI INCREASE OF 19\% II THE RAINIEST YBAR.

I REPORT HERE A DISPARITY IN PRODUCTIVITY BETWEEN RED• KNOBBED AND COMMON COOTS IN SOUTHERI SPAIN THAT COULD BE A CONTRIBUTORY FACTOR IN THEIR DIFFEREMTIAL CONGERVATIOI STATUS. PRODUCTIVITY OF RED·KMOBBED COOTS WAS APPARENTLY MORE SENSITIVE TO VARIATIOI IN 
HABITAT CONDITIONG, THIS SUPPORTS THE SUGGLSTION THAT THE DEGRADATION AND IOSS OF HABITATS DUE TO RECENT CHANGES IN AGRICULTURAL PRACTICES COULD HAVE NEGATIVELY AFFECTED THE PRODUCTIVITY OF RED'KYOBBED COOTS (AMAT \& RAYA 2004), AND THUS MAY PARTIALLY EXPLAII THEIR RECENT POPULATION DECLINE IN SPAIN, HOWEVER, ADULT SURVIVAL RATES ARE ALSO A DETERMINAIT OF POPULATION DYNAMICS (HIRALDO ET AL. 1996, SIRIWARDENA ET AL. 1998, JEXOURIER ET AL. 2005, MORALES IT AL. 2005), AND EX(ES. SIVE HUNTING WAS ALSO SUGGESTED AS A POTENTIAL CAUSE OF THE RED-KMOBBED COOT POPULATION DECLINE (VALVERDE 1960). ESTIMATES OF ADULT SURVIVAL RATES IN THE STUDY AREA ARE ONGOING, USING COOTS MARKED WITH PLASTIC NECK COLLARS. THESE STUDIES WIL HELP TO ELUCIDATE THE RELATIVE IMPORTAICE OF ADULT MORTALITY AND PRODUCTIVITY IN RED. KNOBBED AND COMMON COOT POPULATION GROWTH RATES, AND PREDICT THEIR LONG TERM TRAJECTORIES.

\section{ACKNOWLEDGEMENTS}

I AM GRATEFU TO CONCHITA ALOISO, JaIME A. NIETO, ANTONIO VALERO, ALONSO VARO AND MANOLO VAZQUUZ FOR HELPING WITH THE HIELDWORK, AND TO JUAN A. AMAT, CONCHITA ALONSO, JORDI HIGUEROLA, ANDY J. GREEN AND TWO ANONYMOUS REFEREES FOR HELPFUL COMMENTS ON THIS MasUSCRIPT. THE COMSEJERIA DE MEDIO AMBIENTE, JUYTA DE ANDALUCIA, If ACKYOWLEDGED FOR ALLOWING ME TO WORK WITHIN THE PROTECTED LAGOONG AND PRO. VIDIIG FACILITIE, AND JOSÉ GALINDO AND PEDRO FOR PROVIDING DATA OF RAINFALL, THE STUDY WAS FUNDED BY CONSEJERIA DE MEDIO AMBIENTE, JUNTA DE ANDALUCIA, AND CONSEJO SUPERIOR DE INVESTIGACIONES CIENTIFICAS, CO'FINANCED WITH FEDER FUNDS FROM THE EUROPEAI UNION.

\section{REFERENCES}

Alonso, J.A., Muñoz-Pulido, R., Bautista, L.M. \& Alonso, J.C. 1991. Nest-site selection and nesting success in the azure-winged magpie in central Spain. Bird Study 38: 45-51.

Alonso, J.C. 1984. Estudio comparado de los principales parámetros reproductivos de Passer hispaniolensis y Passer domesticus en España centro-occidental. Ardeola 30: 3-21.

Altmann, J. 1974. Observational study of behaviour: sampling methods. Behaviour 49: 227-267.

Amat, J.A. 1984. Las poblaciones de aves acuáticas en las lagunas andaluzas: composición y diversidad durante un ciclo anual. Ardeola 31: 61-79.

Amat, J.A. 1995. Parent-offspring feeding relationship of coots (Fulica atra) in a varying environment. Behaviour 132: 519-527.

Amat, J.A. \& Raya, C. 2004. Focha Moruna Fulica cristata. In Madroño, A. González, C. \& Atienza, J.C. (eds) Libro Rojo de las Aves de España: 199-202. Dirección General para la Biodiversidad-SEO/Birdlife, Madrid.

Batary, P., Winkler, H. \& Baldi, A. 2004. Experiments with artificial nests on predation in reed habitats. J. Ornithol. 145: 59-63.

Bernis, F. 1964. Información Española sobre Anátidas y Fochas. Época Invernal. Sociedad Española de Ornitología, Madrid.
Brinkhof, M.W.G. \& Cavé, A.J. 1997. Food supply and seasonal variation in breeding success: an experiment in the European Coot. Proc. R. Soc. Lond. B 264: 291-296.

Cramp, S. \& Simmons, K.E.L. 1980. The Birds of the Western Palearctic, Vol. 2. Oxford University Press, Oxford.

Dervieux, A., Isenmann, P., Clamens, A. \& Cramm, P. 1990. Breeding time and breeding performance of the Blue Tit (Parus caeruleus) in two Mediterranean habitats. In Blondel, J., Gosler, A., Lebreton, J.D \& McCleery, R. (eds) Population Biology of Passerine Birds. Springer, Berlin.

Evans, K.L., Duncan, R.P., Blackburn, T.M. \& Crick, H.Q.P. 2005. Investigating geographic variation in clutch size using a natural experiment. Func. Ecol. 19: 616-624.

Fernández-Palacios, J. \& Raya, C. 1991. Biología de la Focha Cornuda (Fulica cristata) en el Bajo Guadalquivir: situación y biología. Alytes 6: 159-185.

Ferrer, X. 1981. Sobre la situación de Fulica cristata en Cataluña. Misc. Zool. 7: 221-222.

Gill, V.A., Hatch, S.A. \& Lanctot, R.B. 2002. Sensitivy of breeding parameters to food supply in Black-legged Kittiwakes Rissa tridactyla. Ibis 144: 268-283.

Halse, S.A. \& Jaensch, R.P. 1989. Breeding seasons of waterbirds in south-western Australia: the importance of rainfall. Emu 89: 232-249.

Hipfner, J.M., Gaston, A.J. \& Storey, A.E. 2001. Nest-site safety predicts the relative investment made in first and replacement eggs by two long-lived seabirds. Oecoogia 129: 234-242.

Hiraldo, F, Negro. J.J., Donazar, J.A. \& Daona, P. 1996. A demographic model for a population of the endangered lesser krestel in southern Spain. J. Appl. Ecol. 33: 1085-1093.

Horsfall, J.A. 1984a. Brood reduction and brood division in Coots. Anim. Behav. 32: 216-225.

Horsfall, J.A. 1984b. Food-supply and egg mass variation in the European Coot. Ecology 65: 89-95.

Hoyt, D.F. 1979. Practical methods of estimating volume and fresh weight of bird eggs. Auk 96: 73-77.

IUCN 1994. IUCN Red List Categories. IUCN, Gland.

Jenouvrier, S., Barbraud, C. \& Weimerskirch, H. 2005. Longterm contrasted responses to climate of two Antarctic seabird species. Ecology 86: 2889-2903.

Johnson, L.S., Ostlind, E., Brubaker, J.L., Balenger, S.L., Johnson, B.G.P. \& Golden, H. 2006. Changes in egg size and clutch size with elevation in a Wyoming population of mountain bluebirds. Condor 108: 591-600.

Lack, D. 1954. The Natural Regulation of Animal Numbers. Clarendon Press, Oxford.

Lack, D. 1968. Ecological Adaptations for Breeding in Birds. Methuen, London.

Livezeay, B.C. 1998. A phylogenetic analysis of the Gruiformes (Aves) based on morphological characters, with an emphasis on the rails (Rallidae). Phil. Trans. R. Soc. Lond. B 353: 2077-2151.

Lu, X. \& Zheng, G.M. 2003. Reproductive ecology of Tibetan Eared Pheasant Crossoptilon harmani in scrub environment, with special reference to the effect of food. Ibis 145: 657-666.

Martin, T.E. 1987. Food as a limit on breeding birds: a life-history perspective. Ann. Rev. Ecol. Syst. 18: 453-487.

Morales, M.B., Bretangnolle, V. \& Arroyo, B. 2005. Viability of the endangered Little Bustard Tetrax tetrax population of western France. Biodivers. Conserv. 14: 3135-3150.

Norment, C.J. 1992. Comparative breeding biology of Harris' sparrows and Gambel's white-crowned sparrows in the northwest territories, Canada. Condor 94: 955-975. 
Perrins, C.M. \& Birkhead, T.R. 1983. Avian Ecology. Blackie, Glasgow.

Romero, R., Guijarro, J.A., Ramis, C. \& Alonso, S. 1998. A 30years (1964-1993) daily rainfall data base for the Spanish Mediterranean Regions: first exploratory study. Int. J. Climatol. 18: 541-560.

Siriwardena, G.M., Baillies, S.R. \& Wilson, J.D. 1998. Variation in the survival rates of some British passerines with respect to their population trends on farmland. Bird Study 45: 276-292.

Taylor, B. \& Van Perlo, B. 1998. Rails: A Guide to the Rails,
Crakes, Gallinules and Coots of the World. Pica Press, Sussex.

Valverde, J.A. 1960. Vertebrados de las marismas del Guadalquivir. Archivos del Instituto de Aclimatación de Almería, Vol. 9, CSIC, Almería.

Weggler, M. 2006. Constraints on, and determinants of, the annual number of breeding attempts in the multibrooded Black Redstart Phoenicurus ochruros. Ibis 148: 273-284.

Wetlands International 2002. Waterbird Population Estimates, 3rd edn. Wetlands International Global Series, No. 12. Wageningen, The Netherlands. 